\title{
WEB BANKING IN BRAZIL
}

Eduardo Diniz

Pesquisador-visitante na Haas School of Business, University of California, Berkely e doutorando na EAESP/FGV.

RESUMO: Este artigo apresenta uma pesquisa preliminar sobre web banking no Brasil, antecedida por uma discussão sobre segurança na Internet e algumas das vantagens e impactos dos serviços bancários pela web. No final, são apresentadas sugestões para futuros estudos sobre web banking.

ABSTRACT: This article will present a preliminary survey of the status of web banking in Brazil, preceded by an explanation about some security problems on the Internet and some advantages and impacts of banking services through the web. It will end with suggestions for further Web banking studies.

PALAVRAS-CHAVE: bancos, world wide web, serviços online, comércio eletrônico.

KEY WOROS: banking, world wide web, internet, online services, electronic commerce. 
1. DAVIDSON, Steven. PC-based home banking: Part I. America's Community Bankerv. 5, n.5, May 1996, pp.38-9.

2. An Internet banking boom is coming...really. US Banker. v. 106, n. 6 , Jun. 1996, p. 20.

3. CREDE, Andreas. Electronic commerce and the banking industry: the requirement and opportunities for new payment systems using the Internet. Journal of Computer-Mediated Communication (Special Issue on Electronic Commerce) v. $1, n .3$.

4. SWANSON, Doug; FLEMING, Cathy. Entering the home-banking market. Credit Union Executive. v. 35, n. 2, Mar./Apr. 1995, pp. 4-8.

5. Idem, ibidem.

6. LUBOVE, Seth. Cyberbanking. Forbes. V. 158, n. 10, Oct. 21,1996 , pp. 108-116.

7. OGILVE, Charles W III. Cyberbanking. Bank Management. v. 72, n. 3, May/Jun. 1996, pp. 14-18.

8. SEGEV, Arie; PORRA, Jaana; ROLDN, Malu. A Bigger Picture of internet Security: The Case of Bank of America. C/TM Working Paper. March, 1997.

9. SEGEV, A.; WAN, D.; BEAM, C.; TOMA, B.; \& WEINROT,D. Financial EDI over the Internet: a Case Study. CITM Working Paper. June, 1995.

10. Financial data encryption code is broken. Wall Street Journal. 19 june 97.
The number of remote services offered by banks has increased dramatically in recent years. Every bank now has to offer services via telephone, fax or PCs. Decrease in the price of computing and increasing utilization of the Internet are the new forces pushing "on-line banking".

Changes in technology, new market demands and pressures from the business environment will create new sources of competitive advantage in the banking sector. All over the world, the Internet is being considered as a vehicle for promote banking services. ${ }^{2}$

All the concerns about on-line security have not blocked the growing presence of financial institutions on the Web. Despite the fact that many of banks are offering little more than information and simple inquiry facilities, they are planning to upgrade in order to provide capability of conducting most traditional banking transactions in the next few years. ${ }^{3}$

The more banks individually explore advantages of creating a page on the World Wide Web, the more the banking industry will experience structural changes. If we are close to the time when "every bank will be using the Internet to attract new customers and deliver services", 4 then it is reasonable to expect some strong impact in the way banking is done today.

The Internet has introduced new payment systems, influenced client expectations for banking services, and will affect bank-customer relations and the competitive environment banks operate under. Besides creating more interactive relationship with clients, banking services through the Internet presents new possibilities for cost reductions and product delivery.

\section{SECURITY ON THE INTERNET}

Among the issues and challenges involved in acquiring the necessary knowhow to run an Internet banking service, security is the most widespread concern for banks as well as for customers. ${ }^{5}$

This concern arises primarily due to expertise of computer "hackers" and the digital nature of the data traveling over the Internet. Some have compared the security provided by the Web with traditional delivery channels such as phone banking,$^{7}$ but tapping one plain phone line means accessing information from only one person whereas, with one interception, a hacker can get information from countless people who releases sensitive data through the Internet. Even when a break-in is detected, it may be impossible to identify the invaders.

Technically, banking on the Internet depends mainly on security of two levels. The first one is ensure that one single online transaction is authentic and securely transmitted. The second is to protect bank computers on the Internet. At the first level security is provided to customers individually. However protecting bank computers on the Internet is more critical because it results in the protection of a database which has information about thousands - in some cases, millions - of customers.

Public key protocols based on encryption techniques protect the information which is transmitted over computer networks, not the communications line. These are largely adopted by transactions through the Web. Protecting the bank's database requires implementing a whole security architecture inside the operating system. Even if there has been a great deal of investment in developing security technologies at both levels, there remains some perception that the Internet is not indeed secure.

That perception is changing slowly, but even so security for banking over the Internet should not be taken as a simple technical solution. Far beyond that, it must be seen as an integral part of corporate security standards addressing information systems and may require a reorganization of business units. ${ }^{8}$

Actually, the Internet can offer high levels of security, ${ }^{9}$ when compared with other security systems used to transmit financial data. Helping to put down the Internet insecurity myth, an executive of a company that produces Internet security systems offered US\$10 mil to anyone who could break the DES (Data Encryption Standard) code, ${ }^{10}$ used to protect financial transactions, including electronic fund 
transfers, and ATM transactions. The code was broken in four months by a team of programmers and researchers, proving that it was not as inviolable as many had thought.

\section{Adding value to banking services}

The benefits the Internet can bring to banking services have to be considered in the ways it adds value to them. ${ }^{11}$ In the following paragraphs some ways to improve banking services using the Web are presented.

\section{Promotion tool}

The first way to add value to banking services and products through the Web is by promotion. This is a safe and low cost way for a bank starting on the Web. Such additional marketing channel will give banks the opportunity to be seen by each one of its on-line clients as well as millions of Web users all over the world. Offering information from branch address to investment options, the bank Web site can be a rich source to actual or potential clients about the company profile, the available products and services, and the financial market.

Available anytime, anywhere, all the information through the Web can do more than simply offer an electronic brochure about their products and services. As an on-line vehicle interactive and customized, the Web is a powerful promotion tool. In this way, the client can help the system to determine his/her needs and fulfill them.

One site might have search tools which help to get the needed information easily and quickly. Providing links of interesting sources of information which help clients get opinions from third parties, a bank site can become an important stop for Web travelers. Reports about the financial market and indices may be made available and special offers might also be presented to specific groups of clients.

Easy access to clients is a good way to promote a bank. Banks should give clients a customized way to consult information about accounts or to read notes about the financial market behavior before making an investment decision. Furthermore, a bank can explore better its knowledge from clients, offering information in the quantity and quality that he/she needs, according to information collected a from regular use of service.

Besides being a promotion tool for bank products and services, the Web site also promotes the company itself. In competitive environments, the ability to offer information about company performance and to build a company's image is as important and decisive for the success of a business as the promotion of its products. The Web as a promotion vehicle links the bank image with advanced technology, specifically targeting the more profitable segment of technology-friendly customers.

\section{New channel for transactions}

The next step to product promotion is conducting the transaction. After getting information from a Web site, a client is able to choose investment options and conduct transactions through the system itself. Making transactions without space or time limitations, since the bank can virtually be available at the preferred place and time of the clients, is a clear advantage to both client and bank.

From the clients' point of view, they receive the ease and comfort of having all the information they need to make decisions at the same place and time they actually make investments. For a bank, it means they can hold clients just after offering them explanations and options directed to their expectations.

Having detailed information about products, clients make investment decisions while on-line. Banks can still offer updated market analyses and other decision support information, presenting graphically the performance of a product. Using on-line software to foresee the profitability expectation of a product is another resource which helps to improve sites. This kind of tool makes the client more comfortable in choosing among many options offered. Since all the analyses are readily available, clients can make transactions right after have decided.
11. BLOCH, Michael; PIGNEUR, Yves \& SEGEV, Arie. On the Road of Electronic Commerce - a Business Value Framework, Gaining Competitive Advantage and Some Research Issues. CITM Working Paper. March, 1996. 


\section{ECONOMY IN THE REALIZATION OF TRANSACTIONS}

For banks, the Web may represent an opportunity to reduce costs of many transactions. In a public network with shared infra-structure, such as the Internet, where information can be transmitted and reused, communication with customers can be improved at lower costs, saving expenses with personnel, telephone, mail and printing. Thus, the Web represents an advantage for companies in marketing, distribution and services to clients.

In fact, the expectation of saving has been an important factor in the consideration of Web banking. In addition to reducing the costs of paper processing ${ }^{12}$ by the increase of fund transfer and other electronic payments, banks believe cost reducing in product distribution can also be obtained. ${ }^{13}$

Keeping records, offering consult files via e-mail, and other interactive ways of attending client solicitations is cheaper than other more traditional ways of client support and also has a role in the building of the image of the company to the market.

Despite the fact that real savings are still not quantified, cost reductions with Web banking services have been expected by banks. Some analyses indicate that the initial costs estimated for the implementation of a Web banking project ${ }^{14}$ is very attractive when compared to the cost of maintaining physical branches. If the costs of implementing a banking site are roughly equivalent to the costs of supporting a branch office, as one study has indicated, ${ }^{15}$ then banks can potentially radically reduce their costs per client.

12. DeLONE, William H.; MARIBOJOC, Roderick G. Educate Your Market for Home-Banking. Bank Marketing. v. 24, n.11, nov 1992, pp. 28-33.

13. MACE, Scott. Getting Your Finances in Order: Home Banking Helps Drive Growing Market. InfoWorld. v.8, n.15, Apr 14, 1986, pp. $26,28$.

14. DAVIDSON, Steven. PC-based home banking: Part II. America's Community Banker. v. 5, n. 6, Jun 1996, pp. 44-45

15. An Internet banking boom is coming...really. US Banker. v. 106, n. 6 . Jun. 1996 , p. 20.

16. SEGEV, A: WAN, D.; BEAM, C.; TOMA B.; \& WEINROT,D. Op. cit.
Banks will be surviving in a rapidly changing and more complex environment with shorter product life cycles. The Web helps to reduce the time to get information from clients, create customized products and deliver them.

\section{Service to client}

In contrast to proprietary home banking systems, which have to be installed in each computer from where it will be used, the Web is much more pervasive and can be virtually in contact with clients 24 hours a day 7 , days of the week.

The ubiquitous characteristic of the Web will permit a much more intense link between bank and clients, since its so easy for them make consulting and transactions. If each event (transaction, consults etc.) can be tracked, the profile of a client can be recorded. Such interaction can create for the bank a better knowledge base of its clients, and give the opportunity for develop marketing strategies which can meet individual needs.

Personalized marketing will make clients come back more often to familiar environment where habits and preferences are known. Different navigation options through the service might become available and, no matter where a specific client is, the system will always recognize $\mathrm{him} / \mathrm{her}$ or even search for them, as with e-mail services.

Studies on relationship marketing indicate that client loyalty can be built by customizing products to their needs. This is especially feasible when the product or service offered for a company have a strong component of information, ${ }^{16}$ case of banking products and services. Systematic data gathering from clients, besides feeding a bank system with information with their preferences, monitors the attendance systems and create a base that will be used as source for perfecting or developing products.

Clients looking for convenience may decide that Web "cookies" are worth the sacrifice of a small lost of privacy. "Cookies" are a form of storage financial information and other pertinent data on the behavior of a client. Future transactions can 
be facilitated if clients do not need reenter many of its personal data at each operation.

Bank knowledge about its more profitable clients and products can also be obtained from regular gathering data. This knowledge helps to focus strategies, giving elements for discontinuation of less profitable products as well as for issuing incentives to more important clients within its portfolio.

\section{DEVELOPMENT OF NEW PRODUCTS}

The Web will also help banks in developing new products. Since information from clients is easier to collect, banks will be capable of more sophisticated analysis of investment behavior, and thus in providing products tailored to clients demands.

New products will fit existing clients needs better as well as offer more to a different set of clients. The information gathered will allow for the adjustment of production to the evolution of market needs, and banks will place clients in a more active role on the creation of the its products, and not only as mere passive consumers.

\section{ORGANIZATIONAL AND TECHNOLOGICAL LEARNING}

In a field where there are no well established models to follow, adoption of the use of the Web necessarily implies a great deal of experimentation. This experimentation is technological as well as organizational, since new technologies will demand new organizational approaches.

Personalized relationship created by the Web will transform organizations. ${ }^{17}$ The product development model aimed at demand implies an organizational structure aimed at demand. To be profitable with the Web, organizations have to familiarize themselves with technology quickly and look for alternatives to make their organizational structure more flexible, in order to assimilate the long term impact of the changes resulting from technology.

The value of the two kinds of learning, technological and organizational, creates new potential for an organization to acquire and explore markets that still are in the beginning stages. In this way, the Web will be creating an opportunity for a true transformation of banking services.

\section{TRANSFORMATIONS IN BANKING SERVICES}

The Web will give opportunity to bring forth new models of business, more than just to help create new products. The more evident aspects of the Web impact is related to role of the intermediation businesses.

There are two main areas in which the impact of business transformation will impact banks: 1) electronics channels for product, services and information distribution, and 2) development of on-line payment systems. ${ }^{18}$

Today banks have a variety of channels for products and services: ATMs - simple and sophisticate - services for telephone and fax, branch banking - traditional and alternative — and home banking via proprietary software. A new channel such as the Web will influence the administration of these channels in cost and in complexity. In addition to support old products and services through the new channel, new products and services may be added to the old channels.

Banking activities will experience an increase with the introduction of a new interactive channel. However this new channel can substitute the old ones in some activities, the impacts of this change will be hard to measure and will depend on the acceptance of new services by clients, on the diversity of on-line services and on costs of connecting the on-line channel with the legacy systems.

Most banks today utilize their own distribution channels for distributing products and services. The development of on-line channels will make banks work in a shared distribution environment. This can create opportunities for new business focuses, based upon the competitive advantages of each organization.

Some organizations will specialize as product developers, becoming wholesale providers. Others will specialize in providing strategic advising services to clients and assisting in building the best
17. BLOCH, Michael; PIGNEUR, Yves \& SEGEV, Arie. Op. cit.

18. Warp speed. The Economist-A survey of technology in finance. October $26^{\text {th }}$, 1996 
possible combination of products developed for third parties - for their investments. ${ }^{19}$ Other will remain integrators, with a strong position in the front of production as well as in the distribution. In fact, these transformations have already been happening in the banking services scenario, but they will tend to accelerate with the consolidation of on-line services through the Web.

On the other hand, the emergence of electronic commerce will demand banks take an aggressive role in the development of electronic payment systems. Some other intermediaries are already emerging especially among software solutions providers - who are interested in maintaining themselves as developers of payment systems for on-line transactions.

Smart cards, electronic checks and other mechanisms to buy products directly through the Web will need the active participation of banks, otherwise they will lose the monopoly that today they have on the payment systems administration.

\section{SERVICES OFFERED THROUGH WEB BY BANKS IN BRAZIL}

For a first look at Web banking in Brazil, we have decided to search the Web sites as a potential client, looking for kinds of services offered by banks to someone who wants to make transactions through the Web. This survey was done in June 1997.

From a list of 227 banks operating in Brazil, 60 banks had some kind of Web presence. Five among these 60 had sites that did not offer information about the bank, because the site, or the organization itself, is being reformulated. From these five banks with Web sites in adaptation phase, however, one has an e-mail address available for contacting with the organization.

19. EINSFELD, Ulrike; ROEMER, Mark; ROSBACH, Peter; SANDBILLER, Klaus; WILL, Andreas. Customer consulting in financial services with distributed knowledge based systems. Discussion Paperno. 69/1995.University of Augsburg.

20. ROLDAN, Malu. Relationship Marketing on the Web is Built on the Links that Bind. CITM Briefing Paper.May, 1997.
Table 1: Banks with web site

\begin{tabular}{|lll} 
Total Number of Banks & 227 & \\
Banks with URL & 60 & $26.4 \%$ \\
\hline Active Sites & 55 & $91.7 \%$ \\
\hline Slte in Adaptation Phase & 5 & $8.3 \%$
\end{tabular}

To have an idea about the size of banks on the Web, we used the ranking of banks of the Exame magazine. ${ }^{20}$ Of the 50 biggest banks ranked by equity, 41 had sites on the Web. Thus $68.3 \%$ of the sites surveyed are among the 50 biggest companies in the sector in Brazil.

Excluding the sites that are in the adaptation phase, we considered the 55 active sites to make this survey's analysis. All of them had at least some basic information about the organization and promoted services and products offered by the bank. The most common information in those sites are the branch addresses $(78.2 \%)$, and the administrative staff components $(43.6 \%)$. Almost half of the sites surveyed $(47.3 \%)$ had some kind of financial information about the banks, but less than one third of them had the complete balance sheet of the companies $(29.1 \%)$.

Table 2: Information within the sites

$\begin{array}{lll}\text { Sites surveyed } & 55 & \\ \text { Branch localization } & 43 & 78.2 \% \\ \text { Staft composition } & 24 & 43.6 \% \\ \text { Balance sheet } & 16 & 29.1 \% \\ \text { Financial information } & 26 & 47.3 \%\end{array}$

All of the sites had information in Portuguese, $54.5 \%$ in English and $9.1 \%$ in Spanish in order to help visitors from different countries who want to get information about the companies. English is the first language on the Internet, so some sites $(9.1 \%)$ adopted it as his first language to a visitor who reaches their Web address.

Table 3: Used language

$\begin{array}{lrl}\text { Portuguese } & 55 & \\ \text { English } & 30 & 54.5 \% \\ \text { Spanish } & 5 & 9.1 \% \\ \text { English as first language } & 5 & 9.1 \%\end{array}$

We also tried to identify resources which help improve interactive options to those who surfs the Web frequently. The most 
used resource were e-mail (72.7\%), links with other sites (52.7\%) and forms to get information $(38.2 \%)$ from visitors. Some sites offer software download $(25.5 \%)$, search engines to look for information internally in the site $(18.2 \%)$ and report downloads $(16.4 \%)$. We also found sites which are used as support tools for recruiting $(10.9 \%)$.

Table 4: Interactlve resources

$\begin{array}{lrr}\text { E-mall } & 40 & 72.7 \% \\ \text { Links to other sltes } & 29 & 52.7 \% \\ \text { Forms to get information } & 21 & 38.2 \% \\ \text { from visitors } & & \\ \text { Software download } & 14 & 25.5 \% \\ \text { Internal search engine } & 10 & 18.2 \% \\ \text { Report download } & 9 & 16.4 \%\end{array}$

Home banking through proprietary software was also promoted in many surveyed sites $(45.5 \%)$. But among the companies which offer this services, only a few had download software capabilities $(20.0 \%)$, with only $21.8 \%$ taking the opportunity to improve on-line banking with simple promotions, downloading of software demonstration without any real interaction capability, or offering a form to receive the software, which will be sent later by regular mail $(1.8 \%)$.

Table 5: Proprietary home banking services promotion

\begin{tabular}{lcc}
$\begin{array}{l}\text { Promotlon of home/office } \\
\text { banking }\end{array}$ & 25 & $45.5 \%$ \\
Promotlon & 12 & $21.8 \%$ \\
Download & 11 & $20.0 \%$ \\
\hline
\end{tabular}

From this survey we could find few banks in Brazil offering services that use the whole capacity of the Web to improve real transactions in the same way their clients have in normal branches or even in ATMs. The ones $(10.9 \%)$ that have already entered in the Web banking age offered basic services such as balance inquiry, transaction history reporting and some investment options. Bill payment functionality and application for new accounts $(5.5 \%)$, requisition of check books $(3.6 \%)$, inter-account transfers and application to receive cards $(7.3 \%)$ are also options which were found.

Table 6: Services banking offered through the Web

\begin{tabular}{lrl} 
Appllcation for opening & 3 & $5.5 \%$ \\
$\begin{array}{l}\text { account } \\
\text { Requisition of check book }\end{array}$ & 2 & $3.6 \%$ \\
\hline Appllcation to receive cards & 4 & $7.3 \%$ \\
Balance inquiring & 6 & $10.9 \%$ \\
Transaction history reporting & 6 & $10.9 \%$ \\
Blli payment & 3 & $5.5 \%$ \\
Inter-account transfers & 4 & $7.3 \%$ \\
\hline Investment options & 6 & $10.9 \%$ \\
Support to Investment & 19 & $34.5 \%$ \\
\hline
\end{tabular}

More sophisticated options such as automated investment advising are still not available, but some banks (34.5\%) have already offered alternatives for supporting the investment decision of their clients through reports and indices which show financial market behavior.

A few banks $(7.3 \%)$ give little more sophisticated options for investment simulation through software downloads or even on-line simulations. But the simulators available are so basic as be useful only in very simple investment making decision.

This survey shows that Web Banking in Brazil is in its very initial phase. However that situation can rapidly change. Although this is only a preliminary study, it is useful to know the reality of what is being offered in terms of Web banking in Brazil. Other more detailed studies must be undertaken for a deeper comprehension about the future of banking transactions through the World Wide Web. Next we will describe some suggestions for further studies. 


\section{FURTHER STUDIES}

The market share of non-Brazilian banks in Brazil is still limited, especially in the retail banking sector. Many of these banks, for example, have Web sites with more transaction resources available in their original countries but which are not offered to their Brazilian clients. It is expected that the Brazilian market will be soon become more widely accessed by foreign banks with the break down of the inflation and deregulation and opening policies taking place by the government, thus that situation is expected to change very fast.

A good way to evaluate this evolution and to expand the conclusions of this study is by looking at banking markets from different countries and do the same kind of evaluation that was done in this study. The comparison of Web banking evolution among different countries could bring some light to the discussion about the situation of each market. Since banking legislation is strictly enforced inside national frontiers, and the Internet and the Web are intrinsically international, this point becomes especially important.

A recent study ${ }^{21}$ showed that the current figures do not express the expectations for the Web banking transactions few years ahead. Many banks are planning to expand their Web banking options in the immediate future and the survey presented here do not reflect these intentions. Consequently the results presented here are likely to change very rapidly. Regular monitoring of Web banking services will show horizontal as well as vertical evolution, with more banks on the Web and with the integration of new services.

Different alternatives for services offered on-line should be compared with traditional services made by branches. This would make it possible to evaluate services offered through the Web in comparison with ATMs, systems of proprietary home banking, and physical branches in terms of kinds of services, amount of transactions, number of clients, operational costs and ways of billing.
Another extension to this study should cover the organizational impacts and the strategies of banks in implementing on-line services. Questions about investments and operational costs, marketing strategies, technical and operational solutions, decisions about outsourcing and plans for services evolving should also be considered in subsequent studies.

More than a simple look at how on-line service banking systems are being implemented nowadays, it is important to conduct analysis which can make projections of the demand for Web services, in order to improve Web and Internet banking services.

This approach could result in models for banks with different profiles. Investment banks surely will have different services online models from banks focused on the retail market. Since each market demands different approaches, the first one could specialize in creating advising products for investor clients, for example, while the others could reinforce services for retail clients.

Another potential study is how the Web could affect client loyalty to banks. The development of products based on demand has the potential to create links which will help keep banks closer to their clients. At the same time, the universality of the Internet opens to the clients the opportunity to have all the banks in the world at his/her hands.

The pace and the problems for adoption of on-line service banking by users, that evaluate difficulties related to increased utilization and implementation of new payment systems, such as the smart card and the electronic check, should be also be considered. This is a very sensitive and important to banks that nowadays still have the control of most of the payment systems but are suffering more and more competition from non-bank organizations.

The field to study is wide and give a great opportunity for many different contributions. This very modest contribution presented herein intend only to point some basic questions that help to understand the Brazilian scene for on-line banking services.
21. On-line for cyberbanking. Financial Technology International Bulletin. v. 12 n. 6, Feb. 1995, p. 9. 